\title{
Molecular Analysis of PRT
}

\author{
○藤村 寛 有山重美 大谷達夫 大下芳人 岡崎幸紀 \\ 竹本忠良 \\ OHiroshi Fujimura, Shigemi Ariyama, Tatuo Otani, \\ Hideto Oshita, Yukinori Okazaki, Tadayoshi Takemoto \\ 山口大学医学部第一内科
}

First department of Internal medicine, Yamaguchi University. school of medicine.

\begin{abstract}
ABSTRUCT
Characteristic ESR spectrum is detected only after PRT. This ESR spectrum was considered triplet signal which is peculiar to $R_{2} N O$ radical. We regarde this ESR spectrum as a product of $\mathrm{HpD}$ after PRT. We believe the strength of ESR spectrum is correlative with the volume of $\mathrm{HpD}$ which is absorped into cells.

Based on this opinion, we measured the ESR spectrum after PRT with patient. and animals. In the result, we conclude that the second day after $\mathrm{HpD}$ injection is most optimum condition for PRT.
\end{abstract}

\section{はじめに}

最近、胃癌に対する新しい治療法として、 hematoporphyrin derivative (HpD) による photoradiation therapy(PRT)か注目されている。 しかし、本法の鼠適条件の設定などには多くの問 題点が残されています。そてでわれわれの研究グ ループは電子スピン其鳴法 electron spin resonance (ESR)の手法を導入し、光化学効果 photoradiation effectの解析を分子化学的经行った。その 第 6 巻第 3 号 1986 年1月
経時的変化を癌部、非癌部において、患者や動物 実験により観察し、先に述べた問題点の検討を行 ってみた。

器具および使用薬㨈

本研究に使用したのはSpectra Physics 社製 Model 770 型 Argon laser 発振器、門田製作所製 laser 用内視鏡装置、西坂らの開発した round tip 型 quartz fiber, Oncology Research製 $\mathrm{HpD}$ 、日 
本電子製 ESR spectrometer, JES-ME-1X、石 英製 ESR用試料管、液体窒素、画像解析用コンピ ユータシステムなどである。

\section{方 法}

1）Wister 系雄性ラットにHpDを胃内、腹腔内に 投与し、12, 24, 36, 48時間後に胃粘膜にArgon laserを照射し組織を採取する。

(HpD $5.0 \mathrm{mg} / \mathrm{kg}$, Argon laser $500 \mathrm{~mW}, 20 \mathrm{~min}$ )

2）ビーグル犬に $\mathrm{HpD}$ を静脈内投与し、その 12 ,

$24 ， 48 ， 72 ， 168$ 時間後にArgon laser 照射し直 視下生検により組織を採取する。

(HpD 2.5mg/kg, Argon dye laser $200 \mathrm{~mW}, 20 \mathrm{~min}$ )

3）胃癌患者を対象に photoradiation therapy (PRT) の前後で直視下生検により組織を採取する。 (HpD $2.5 \mathrm{mg} / \mathrm{kg}$, Argon laser $500 \mathrm{~mW}, 20 \mathrm{~min}$ )

4）1)〜3)の各々の組織を操取後直ちに泠却した 生食で洗净し、石英製の試料管につめて溶封す る。

5）ジュワーびんに液体窒素を満たし、中心に試 料管を扱入し凍結した後にESR spectrometer で測定を行う。

\section{結果と考察}

ヒトにおける photoradiation therapy 後のERS スペクトルでは、 3300 Gauss 付近に 3 本の ESR

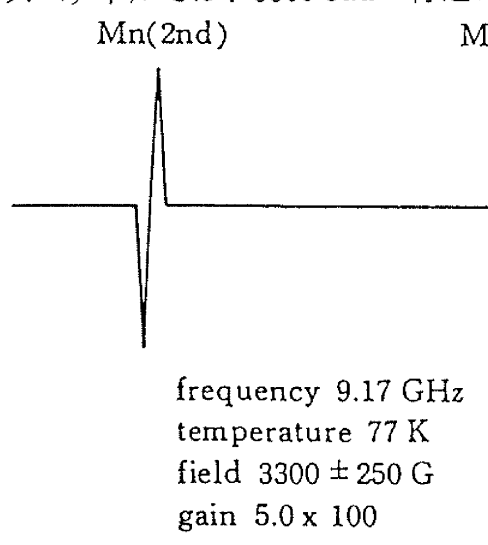

シグナルが認められた。ESRシグナルをコンピュ 一タにより解析してみた（Fig. 1)。乙れらのシグ ナルはそれぞれ、g值が 1.9998，2.0099，2.0201 の位置に等強度でしかも 15.1 Gaussの等間隔な3 本のシグナルであった。このスペクトルの信号強 度は内部標準物質 $\mathrm{Mn}^{2+}$ のそれよりやや弱く、

$\mathrm{HpD}$ 溶液にみられたシグナルとはまったく異なる むのであった。

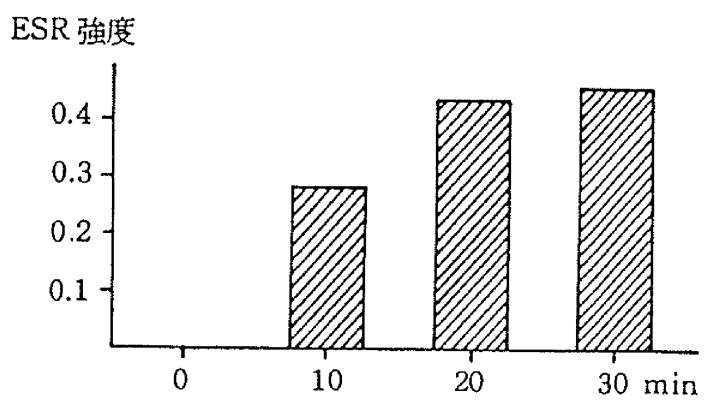

Fig. 2 laser 照射時間によるESR の変化

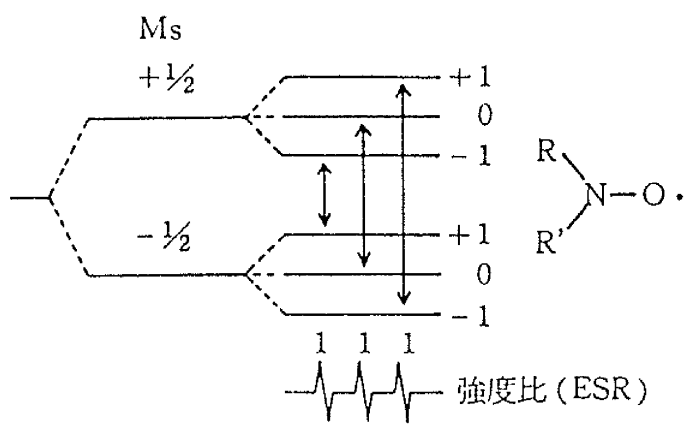

Fig. 3 N核によ万超微絊梅造

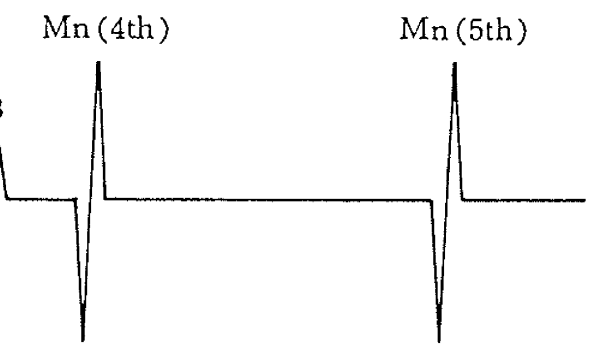

response $0.3 \mathrm{sec}$ mod. width $2.0 \times 10 \mathrm{G}$ $\stackrel{\leftrightarrow}{\longleftrightarrow} \mathrm{I}$ power $20 \mathrm{~mW}$ sweep $10 \mathrm{~min}$

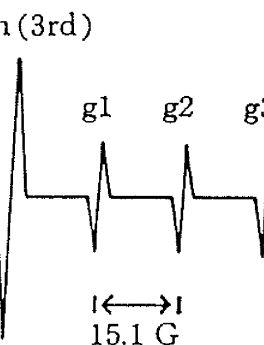

sweep 10 min
3 rd $\mathrm{Mn} \sim 4$ th $\mathrm{Mn} 86.9 \mathrm{G}$ $\mathrm{g}(4$ th $\mathrm{Mn})=1.981$

$\mathrm{gl}=1.9998$

$\mathrm{g} 2=2.0099$

$\mathrm{g} 3=2.0201$

Fig. 1 光化学治療後の ESR スペクトル 
Argon laserの照射時間を変えてみると、Fig.2 のようにESRスペクトルの信号強度も变化してお り、照射前では特異的なシグナルはまったく検出 されなかった。照射後20分までは急速に信号の強 度が増加することが観察された。このシグナルむ 温度変化や時間経過に対してはきわめて安定なも のであった。

てのようにして得られた 3 本線 (triplet) の等間 隔、等強度のシグナルについて、われわれは $\mathrm{R}_{2}$ NO・ラジカルと考えた。Fig.3にみられるように ${ }^{14} \mathrm{~N}$ 核のスピン量子数は1であるから、各電子スピン の準位は 3 となり、電子スピン $\mathrm{Ms}$ の準位は ${ }^{14} \mathrm{~N}$ 核 の核スピンとの相互作用により 3 つの準位に分裂 し、選択律により 3 本の等間隔、等強度の ${ }^{14} \mathrm{~N}$ 核 の超微細構造 hyperfine structure； hfs が観察さ れると考えられる。このようなESRスペクトルの 出現する理由としては、PRTによ りポルフィリン骨格がoxidation により切断され、 $\mathrm{R}_{2} \mathrm{NO}$ ラジカル が発生すると推測される。

そてでラットとビーグル犬を用 いた実験を行った。正常ラットを 用いて、HpD $5.0 \mathrm{mg} / \mathrm{kg}$ を胃内投 与、腹腔内投与したのちの ESR 信号強度をFig.4亿示す。この表 より投与後、12時間から 36 時間ま でにHpDがすみやかに排泄される ことがわかる。次に、ENNGを用 いて発癌させたビーグル犬の癌部、
非癌部のPRT後のESR信号強度をFig. 5に示す。 正常部では、ラットと同様に48時間までに $\mathrm{HpD}$ がすみやかに排泄されています。また、正常部と 癌部を比較してみると、投与後12時間、24時間で は有意差は認めないが、48時間以後では癌部で高 梿を示し、有意差がみられる。ビーグル犬におけ るPRT 後のESR信号強度比をグラフ (Fig. 6) に示 す。黑丸が癌部、白丸が正常部をあらわしている。

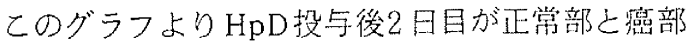
の HpD含有量の差が最大となり、PRTにおける A rgon レーザーの照射効率があっとも良いと考え た。

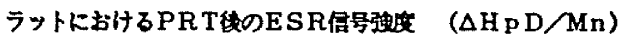

\begin{tabular}{|c|c|c|c|c|c|}
\hline & コントロール & 128封间 & 24時间 & 36 時泪 & 48时称 \\
\hline F内投与 & $(-)$ & $2.10 \pm 0.24$ & $0.63 \pm 0.19$ & $0.19 \pm 0.02$ & $0.10 \pm 0.02$ \\
\hline W陸内投与 & $(-)$ & $0.25 \pm 0.02$ & $0.19 \pm 0.03$ & $0.10 \pm 0.02$ & $0.09 \pm 0.01$ \\
\hline $\begin{array}{l}* 1-* 2 \\
* 2-* 3 \\
* 3-* 4 \\
* 5-* 6 \\
* 6-* 7\end{array}$ & $\begin{array}{l}p<0.01 \\
p<0.05 \\
p<0.01 \\
p<0.05 \\
p<0.05\end{array}$ & $\begin{array}{ll}* 7-* 8 & \text { n.s. } \\
* 1-* 5 & p<0.0 \\
* 2-* 6 & p<0.0 \\
* 3-* 7 & p<0.0 \\
* 4-* 8 & \text { n.s. }\end{array}$ & & & \\
\hline
\end{tabular}

Fig. 4

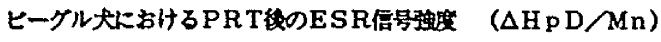

\begin{tabular}{|c|c|c|c|c|c|c|}
\hline & コントロール & 12时谓 & 24时赫间 & 48 时拍 & 72 时指 & 168時间 \\
\hline 正 常 & $(-)$ & $0.08 \pm 0.02$ & $\begin{array}{r}0.10 \pm 0.02 \\
\end{array}$ & ${ }^{0.04 \pm 0.01}$ & $0.02 \pm 0.04$ & $(-)$ \\
\hline 䓌 & $(-)$ & $0.08 \pm 0.04$ & $0.09 \pm 0.01$ & ${ }^{0.09 \pm 0.02}$ & $0.06 \pm 0.05$ & $0.03 \pm 0.01$ \\
\hline $\begin{array}{l}* 1- \\
* 2- \\
* 3-\end{array}$ & $\begin{array}{l}p<0.05 \\
p<0.01 \\
\text { n.s. }\end{array}$ & 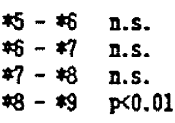 & $\begin{array}{l}* 1-* 5 \\
* 2-* 6 \\
* 3-* 7 \\
* 4-* 8\end{array}$ & $\begin{array}{l}\text { D.s. } \\
\text { n.s. } \\
\text { p<0.05 } \\
p<0.01\end{array}$ & & \\
\hline
\end{tabular}

Fig. 5 


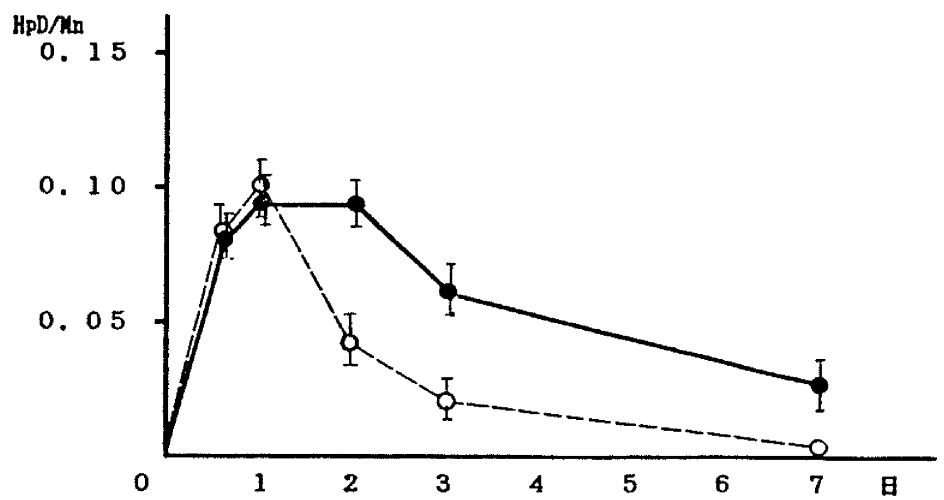

Fig. 6

結 論

1) Argon laserを用いた photoradiation therapy (PRT)の解析を行うため、ラットの胃粘膜、イ ヌ、ヒトの胃癌についてESRスペクトルの測定 を行った。

2） $\mathrm{HpD}$ 投与前のコントロール群では、ラット、 イヌ、ヒトいずれも特異的なスペクトルは検出 されず、PRT後にのみtriplet シグナルが検出 された。

3）乙のtripletシグナルはポルフィリン 環の開裂に よって生じた R NO・ラジカルと考えられ、ま た、信号強度 $\Delta \mathrm{HpD} / \mathrm{Mn}$ はPRT の効果を表わし ていると思われた。

4）ラットの実験では、 $\Delta \mathrm{HpD} / \mathrm{Mn}$ は12時間から 36時間にかけて急激に減少を示し、正常胃粘膜 ではHpDはすみやかに排泄されると考えられた。

5）ビーグル犬を用いた実験では、癌部は正常部 に比較してHpDの排泄は遅延しており、1日目 までは統計的に有意差はないが 2 日目以降では 有意差が認められた。

6）今回の実験では種特異性は多少みられるが $\mathrm{HpD}$ 投与後 2 日目が正常部之癌部の粘膜内の $\mathrm{HpD}$ 含有量の差が最大となり、PRTにおける
Argonレーザー照射の効率がむっとも良いと考 えた。 